\title{
Persepsi Mahasiswa Terhadap Proses Pembelajaran Kemahiran Bahasa
}

(Mata Kuliah Kemahiran Berbicara di Empat Program Studi, Fakultas Sastra, Universitas Al Azhar Indonesia)

\author{
Faisal Hendra ${ }^{1}$
}

\author{
${ }^{1}$ Program Studi Sastra Arab, Fakultas Sastra, Universitas Al Azhar Indonesia \\ Kompleks Masjid Agung Al Azhar, Jalan Sisingamangaraja, Kebayoran Baru, Jakarta Selatan 12110
}

Penulis untuk Korespondensi/Email:_faisal_2104@uai.ac.id

\begin{abstract}
Abstrak - Keberhasilan penerapan kurikulum pembelajaran bahasa asing diperguruan tinggi harus didukung dengan kemampuan profesional pendidik dan lembaga pendidikan mengawal pelaksanaan lima unsur yang ada dalam kurikulum. Kelima unsur ini adalah: tujuan yang ingin dicapai dalam pengajaran bahasa asing, bahan ajar yang digunakan, metodelogi penganjaran yang dipakai oleh dosen, alat bantu pengajaran yang mendukung proses pembelajaran bahasa dan yang terakhir proses evaluasi yang digunakan dosen dalam menentukan sejauhmana keberhasilan pembelajaran bahasa asing yang dipelajari. Keseimbangan lima unsur dalam pembelajaran bahasa asing di Fakultas Sastra, Universitas Al Azhar Indonesia menjadi satu keharusan untuk diterapkan. Dari hasil penelitian ini didapatkan data bahwa lima unsur kurikulum dalam pengajaran bahasa asing di Fakultas Sastra sudah dilaksanakan dengan baik walaupun dibeberapa sisi masih perlu untuk ditingkatkan lagi. Untuk mengembangkan kurikulum dan meningkatkan proses pembelajaran kemahiran berbahasa asing di Fakultas Sastra, Universitas Al Azhar Indonesia kedepannya, maka penelitian ini dilakukan.
\end{abstract}

Kata kunci: persepsi, mahasiswa, proses pembelajarn, kemahiran berbahasa

Abstract - The success of the curriculum of foreign language implementation at a University level should be supported by the educator's professional skills and educational institutions itself that supports the implementation of the five elements in the curriculum. These five elements are: the goal in teaching foreign languages, the teaching materials, the teaching methodologies used by lecturers, the teaching aids that support the process of language learning and finally, the evaluation process used by lecturers in determining how far the success of the foreign language learning studied has achieved. The balance of these five elements in foreign language learning at the Faculty of Letters, Al Azhar University of Indonesia becomes a must to apply. From the results, this study obtained data that the five elements of the curriculum in the teaching of foreign languages in the Faculty of Letters has been implemented well, although some areas still need a lot of improvement. To develop the curriculum and improve the process of learning foreign language proficiency in the Faculty of Letters, Al Azhar University of Indonesia in the future, this research is conducted.

Keywords: perception, student, learning process, language proficiency

\section{PENDAHULUAN}

Latar Pokok Bahasan

Kerbicara, menulis dan membaca) merupakan kemahiran penting yang ingin dicapai dalam proses pembelajaran bahasa asing, di Fakultas Sastra, Universitas Al Azhar Indonesia (UAI).

Secara umum dalam konteks pembelajaran Bahasa, pengajaran bahasa Asing (Arab, China, Inggris dan Jepang) di Fakultas Sastra bertujuan untuk mengembangkan keterampilan 
berbahasa mahasiswa secara lisan maupun tulisan. Dengan keterampilan lisan, mahasiswa diharapkan menguasai sejumlah kosa kata dan struktur kalimat dan dapat berbicara secara aktif; dengan keterampilan tulisan mahasiswa diharapkan mampu membaca dan memahami tentang teks-teks berbahasa, terutama yang berkaitan erat dengan materi yang dipelajari.

Pembelajaran bahasa asing di Fakultas Sastra, Universitas Al Azhar Indonesia mengacu kepada kurikulum 2013, dimana pada kurikulum ini diarahkan kepada beberapa peminatan, peminatan bahasa (penerjemahan) dan peminatan Susastra (budaya) dan lingguistik. Ketiga peminatan ini disesuaikan dengan tuntutan perkembangan dunia pendidikan dan harapan masyarakat lulusan perguruan tinggi bisa diterima keilmuannya. Atas dasar inilah program studi dilingkungan Fakultas Sastra UAI pada tahun 2013, mencoba mendesain pengembangan kurikulumnya yang diarahkan untuk mampu mengantarkan mahasiswanya kelapangan kerja yang ingin mereka tekuni setamatnya mereka mengenyam pendidikan di Fakultas Sastra UAI.

Setelah sekian lama pelaksanaan proses pembelajaran bahasa asing di FS Universitas al Azhar Indonesia yang berpedoman pada kurikulum yang berjalan, maka sudah saatnya dilakukan satu evaluasi yang sifatnya menyeluruh untuk melihat, menganalisis, dan menilai hasil akhir dari proses pembelajaran. Evaluasi tidak hanya dilakukan kepada mahasiswa sebagai objek diterapkannya kurikulum yang sudah berjalan. Akan tetapi juga dilakukan terhadap kinerja dosen serta metodologi yang digunakan dalam pembelajaran sebagai pelaksana langsung proses pembelajaran di Universitas.

\section{Tujuan Penelitian}

Tujuan utama yang ingin dicapai dari penelitian ini adalah untuk mendapatkan data guna mengevaluasi kurikulum dan proses pengajaran kemahiran berbicara bahasa asing yang selama ini diajarkan di Fakultas Sastra dari cara pandang mahasiswa. Hasil yang didapatkan akan menjadi dasar pengembangan kurikulum Fakultas Sastra kedepannya.

\section{Batasan masalah Penelitian}

Batasan penelitian ini diturunkan dalam bentuk pertanyaan yang berhubungan dengan penelitian sbb:

1. Bagaimanakah persepsi mahasiswa terhadap proses pembelajaran bahasa asing dari sudut tujuan yang ingin dicapai dalam proses pembelajaran kemahiran bahasa asing?

2. Bagaimanakah persepsi mahasiswa terhadap bahan ajar yang digunakan untuk mencapai tujuan pembelajaran kemahiran bahasa asing yang diajarkan?

3. Bagaimanakah persepsi mahasiswa terhadap metode pengajaran yang diterapkan dalam mengajarkan mata kuliah kemahiran berbahasa asing?

4. Bagaimanakah persepsi mahasiswa terhadap alat bantu yang digunakan dalam mengajar mata kuliah kemahiran berbahasa?

5. Bagaimanakah persepsi mahasiswa terhadap teknik evaluasi yang digunakan dalam pengajaran bahasa asing?

\section{KERANGKA TEORI}

\section{Hakikat Belajar}

Belajar merupakan kegiatan paling pokok dalam proses belajar mengajar manusia. Terutama dalam pencapaian tujuan institusional suatu lembaga pendidikan. Hal ini menunjukkan bahwa berhasil tidaknya suatu pencapaian tujuan pendidikan tergantung kepada bagaimana proses belajar mengajar yang dialami oleh individu.

Menurut Winkel, belajar adalah semua aktivitas mental atau psikis yang berlangsung dalam interaksi aktif dalam lingkungan, yang menghasilkan perubahan-perubahan dalam pengelolaan pemahaman. Sementara menurut Ernest R. Hilgard dalam (Sumardi Suryabrata, 1984: 252) belajar merupakan proses perbuatan yang dilakukan dengan sengaja, yang kemudian menimbulkan perubahan, yang keadaannya berbeda dari perubahan yang ditimbulkan oleh lainnya. 
Siahaan (2005:2) berpendapat bahwa belajar adalah suatu bentuk pertumbuhan atau perubahan dalam diri seseorang yang dinyatakan dalam cara bertingkah laku yang baru berkat pengalaman dan latihan. Tingkah laku yang baru itu misalnya dari tidak tahu menjadi tahu, timbulnya pengetahuan baru, serta timbul dan berkembangnya sifat-sifat sosial dan emosional.

Paling sedikit ada lima macam perilaku perubahan pengalaman dan dianggap sebagai faktor penyebab dasar dalam belajar. (Ratna Willis, 1988: 25) pertama pada tingkat emosional yang paling primitif, terjadi perubahan-perubahan perilaku diakibatkan dari perpasangan satu stimulus tak terkondisi dengan suatu stimulus terkondisi. Sebagai suatu fungsi pengalaman, stimulus terkondisi itu pada suatu waktu memperoleh kemampuan untuk mengeluarkan respon terkondisi. Bentuk belajar semacam ini disebut belajar responden, dan menolong kita untuk memahami bagaimana peserta didik menyenangi atau tidak menyenangi sekolah atau mata peljaran. Kedua, dibahas belajar kontinyuitas yaitu bagaimana dua peristiwa dipasangkan satu dengan yang lain pada suatu waktu dan hal ini banyak kita alami. Kita melihat bagaimana asosiasi ini dapat menyebabkan belajar dari drill. Ketiga, kita belajar bahwa konseksuensi-konsekuensi perilaku mempengaruhi apakah perilaku itu akan diulangi atau tidak. Belajar semacam disebut belajar aperant. Keempat, pengalaman belajar sebagai hasil-hasil observasi manusia dan kejadian-kejadian kita belajar dari modelmodel, dan masing-masing kita mungkin menjadi suatu model bagi ornag lain dalam belajar observasional. Kelima, belajar kognitif terjadi dalam kepala kita, bila kita melihat dan memahami peristiwa-peristiwa disekitar kita dan untuk menjawab pertanyaan.

\section{Hakikat Hasil Belajar Bahasa}

Hasil belajar merupakan perubahan perilaku akibat interaksi individu dengan lingkungan. Hal ini dapat diartikan bahwa seseorang dikatakan telah belajar, jika ia dapat melakukan sesuatu yang tidak dapat dilakukan sebelumnya (Sumiati, 2008: 38). Proses belajar terlaksana melalui berbagai kegiatan yang khas dan mempunyai salurannya sendiri serta hasilnya sendiri (perubahan dalam sikap atau tingkah laku yang tercapai dan tampak dalam perestasi tertentu).
Menurut Winkel (1987: 9) terdapat lima kategori hasil belajar, yaitu:

1. Keterampilan motorik, yaitu melibatkan bagian-bagian badan yang bergerak menurut pola tertentu secara otomatis, urutan gerak teratur dan berjalan tanpa disertai pikiran tentang apa yang harus dilakukan dan mengapa dilakukan.

2. Sikap, adalah kecenderungan menerima atau menolak suatu hal (aspek afektif) serta bentuk tingkah laku sebagai konsekuensi suatu pilihan.

3. Kemahiran intelektual, yaitu kemampuan bergaul dengan lingkungan di sekitarnya dan dengan dirinya sendiri secara simbolis, lambang, kata-kata, gambar, maupun tulisan.

4. Informasi verbal, yaitu pengetahuan yang dimiliki dengan menggunakan bahasa baik bila menggali informasi maupun bila menyampaikan informasi/ pengetahuan.

5. Pengetahuan kegiatan intelektual, yaitu konsep untuk mengatur intelektualnya sendiri (mengatur jalan pikirannya sendiri untuk memecahkan masalah yang dihadapi).

Hasil belajar bahasa asing dapat diartikan sebagai semua perubahan di bidang perilaku kemampuan di bidang bahasa asing mencakup menyimak, berbicara, membaca dan menulis serta perubahan dart tidak tahu menjadi tahu dan dari tidak bisa menjadi bisa menurut perubahan sikap dan perilakunya selama terjadinya proses belajar bahasa asing. Agar hasil bahasa asing dapat mencapai prestasi yang diharapkan, maka diperlukan sebuah proses pembelajaran yang matang sehingga kita mampu menyerap sebanyak mungkin materi bahasa asing yang diajarkan oleh guru/dosen atau sumber belajar lainnya.

\section{Hakikat Persepsi}

Menurut kamus lengkap psikologi, persepsi adalah: (1) Proses mengetahui atau mengenali objek dan kejadian objektif dengan bantuan indera, (2) Kesadaran dari proses-proses organis, (3) (Titchener) satu kelompok penginderaan dengan penambahan arti-arti yang berasal dari pengalaman di masa lalu, (4) variabel yang menghalangi atau ikut campur tangan, berasal dari kemampuan organisasi untuk melakukan pembedaan diantara perangsang-perangsang, (5) kesadaran intuitif mengenai kebenaran langsung atau keyakinan 
yang serta merta mengenai sesuatu (Chaplin, 2006:358).

Definisi persepsi menurut para ahli sangat beragam, seperti yang dikemukakan berikut ini. Persepsi menurut Epstein \& Rogers (dalam Stenberg, 2008:105) adalah seperangkat proses yang dengannya kita mengenali, mengorganisasikan dan memahami cerapancerapan inderawi yang kita terima dari stimuli lingkungan.

Menurut Wittig (1977:76) persepsi adalah proses menginterpretasikan stimulus oleh seseorang (perception is the process by which a person interprets sensory stimuli). Persepsi muncul dari beberapa bagian pengalaman sebelumnya.

Secara etimologis, persepsi atau dalam bahasa Inggris perception berasal dari bahasa Latin perceptio; dari percipere, yang artinya menerima atau mengambil. Istilah persepsi dapat didefinisikan sebagai suatu proses aktivitas seseorang dalam memberikan kesan, penilaian, pendapat, merasakan dan menginterpretasikan sesuatu berdasarkan informasi yang ditampilkan dari sumber lain (yang dipersepsi).

Menurut Rakhmat Jalaluddin (1985: 51), persepsi adalah pengalaman tentang objek, peristiwa, atau hubungan yang diperoleh dengan menyimpulkan informasi dan menafsirkan pesan. Sebagai cara pandang, persepsi timbul karena adanya respon terhadap stimulus. Menurut John R. Wnburg dan William W. Wilmot, persepsi dapat didefinisikan sebagai cara organisme memberi makna. Sedangkan menurut Rudolph F. Verderber persepsi adalah proses penafsiran informasi inderawi. (Deddy Mulyana, 2005: 167).

Persepsi tidak timbul begitu saja, akan tetapi dipengaruhi oleh beberapa faktor. Faktor-faktor inilah yang menyebabkan mengapa dua orang yang melihat sesuatu yang sama mungkin memberikan interpretasi yang berbeda tentang apa yang mereka lihat tersebut. Dalaam Sobur (2003: 446), dijelaskan bahwa dalam persepsi terdapat tiga komponen utama yaitu:

1. Seleksi, merupakan proses penyaringan oleh indera terhadap rangsangan dari luar, intensitas dan jenisnya dapat banyak atau sedikit.

2. Interpretasi, yaitu proses mengorganisasikan informasi sehingga mempunyai arti bagi seseorang. Untuk mengadakan pengkategorian informasi yang diterimanya, yaitu proses mereduksi informasi yang kompleks menjadi sederhana.

3. Reaksi, merupakan persepsi yang kemudian diterjemahkan dalam bentuk tingkah laku sebagai reaksi.

Sedangkan menurut Deddy Mulyana (2005: 168-170), persepsi meliputi:

1. Penginderaan (sensasi) melalui alat-alat indera (indera peraba, indera penglihat, indera pencium, indera pengecap, dan indera pendengar). Sensasi merujuk pada pesan yang dikirimkan ke otak melalui penglihatan, pendengaran, sentuhan, penciuman, dan pengecapan. Reseptor inderawi adalah penghubung antara otak manusia dan lingkungan sekitar.

2. Atensi. Atensi tidak terelakkan karena sebelum kita merespon atau menafsirkan kejadian atau rangsangan apapun, kita harus terlebih dahulu memperhatikan kejadian atau rangsangan tertentu.

3. Interpretasi, merupakan tahap paling penting dalam persepsi. Kita tidak dapat menginterpretasikan makna setiap objek secara langsung, melainkan menginterpretasikan makna informasi yang anda percayai mewakili objek tersebut.

Dari definisi-definisi yang telah disebutkan diatas dapat ditarik kesimpulan bahwa persepsi merupakan suatu hal yang pasti dialami oleh setiap orang melalui informasi ataupun rangsangan yang datang dari lingkungan sekitarnya. Segala rangsangan ini diterima oleh panca-panca indera untuk kemudian diproses.

\section{Hakikat Mengajar}

Menurut William H Burton: "Mengajar adalah upaya memberikan rangsang (stimulus), bimbingan, pengarahan dan dorongan kepada siswa agar terjadi proses belajar". Burton memandang pelajaran hanya sebagai bahan perangsang saja sedangkan arah yang akan dituju dengan proses belajar adalah tujuan pengajaran yang akan diketahui oleh siswa. Jadi yang terpenting dalam mengajar bukan 
saja upaya guru dalam menyampaikan materi, melainkan bagaimana siswa dapat mempelajari materi pelajaran sesuai dengan tujuan. Hal ini berarti bahwa usaha guru hanya merupakan serangkaian peristiwa yang dapat mempengaruhi kita untuk belajar. Disini peran guru berubah, guru bukan hanya berperan sebagai penyampai informasi melainkan sebagai "director and facilitator' yaitu pengarah dan pemberi fasilitas untuk terjadinya proses belajar. Sedangkan menurut Mohammad Uzer Usman dalam bukunya "Menjadi Guru Profesional", menyatakan bahwa: Mengajar pada prinsipnya adalah membimbing siswa dalam kegiatan belajar-mengajar atau mengandung pengertian bahwa mengajar merupakan suatu usaha, mengorganisasi lingkungan dalam hubungannya dengan anak didik dan bahan pengajaran yang menimbulkan proses belajar.

\section{Hakikat Kompetensi Mengajar}

Mengajar merupakan suatu proses yang kompleks, tidak hanya sekadar menyampaikan informasi dari pengajar kepada pelajar. Banyak kegiatan atau tindakan yang harus dilakukan terutama bila menginginkan hasil belajar yang lebih baik bagi seluruh pelajar. Oleh karena itu di dalam proses belajar mengajar dibutuhkan kompetensi belajar.

Kompetensi merupakan peleburan dari pengetahuan (daya pikir), sikap (daya kalbu dan keterampilan), daya fisik, dan diwujudkan dalam bentuk perbuatan (segala, 2009 :23). Mengajar sebagai suatu keterampilan merupakan aktualisasi ilmu pengetahuan teoritis kedalam interaksi belajar mengajar (djamarah, 1994 :31). Terdapat komponenkomponen kompetensi yang dibutuhkan oleh pengajar, yaitu:

1. Kompetensi kepribadian: Menurut Djamarah (1994: 50) kepribadian adalah keseluruhan dari individu yang terdiri dari unsur psikis dan fisik. Sedangkan menurut segala (2009: 23), kepribadian mencakup semua unsur baik fisik maupun psikis, sehingga dapat diketahui bahwa setiap tindakan dan tingkah laku seseorang merupakan cermin dari kepribadian seseorang.

2. Kompetensi pedagogik: Menurut Sagala (2009: 32) kompetensi pedagogik merupakan kemampuan dalam pengelolaan peserta didik. Sedangkan menurut Yanin dan Maisah (2010: 9) kompetensi pedagogik meliputi pemahaman terhadap peserta didik, perencanaan, dan pelaksanaan evaluasi hasil belajar, dan mengembangkan peserta didik untuk mengaktualisasikan potensi yang dimilikinya.

3. Kompetensi profesional: Yamin dan Maisah (2010: 11) menyatakan bahwa kompetensi profesional merupakan penguasaan materi pelajaran secara luas dan mendalam. Setiap guru atau pengajar sebagai seorang yang profesional maka harus memiliki kompetensi keguruan yang cukup.

4. Kompetensi sosial: Menurut Yamin dan Maisah (2010: 12), Kompetensi sosial merupakan kemampuan guru untuk berkomunikasi dan bergaul secara efektif dengan peserta didik, sesama pendidik, tenaga pendidikan orang tua/ wali peserta didik dan masyarakat sekitar.

\section{Persepsi Terhadap Kompetensi Mengajar}

Berbagai upaya dapat dilakukan untuk menentukan tingkat kompetensi mengajar, ini dapat dilakukan dengan menggunakan berbagai sumber, metode dan berbagai kriteria lain seperti dari teman sejawat, departemen pendidikan, pimpinan,catatan administrator serta dari siswa. Tetapi pada prinsipnya sumber informasi haruslah orang-orang yang berkesempatan

Untuk mengobservasi secara langsung program belajar mengajar yang dilakukan, Sastra Wijaya mengatakan bahwa: "Informasi yang diberikan siswa dapat dijadikan landasan perbaikan proses pengajaran". Pendapat tersebut cukup beralasan karena: pertama evaluasi dari siswa memberi informasi secara langsung dari konsumen bersifat akurat daripada pengunjung sesaat, dan kedua karena siswa banyak menerima pelajaran dari guru/dosen lain sehingga mempunyai dasar pembanding yang baik yaitu penampilan kompetensi guru yang lain. Meskipun penilaian terhadap kompetensi tersebut dilakukan pada suatu moment tertentu tetapi sebenamya hasil pengamatan itu didasarkan pada pengamatan dalam waktu yang relatif lama. Kemampuan atau kompetensi mengajar seorang guru yang dapat diamati secara langsung oleh siswa saat memberikan pelajaran di kelas yang meliputi: kompetensi penguasaan bahan pelajaran, kompetensi 
pengelolaan program belajar mengajar, kompetensi pengelolaan kelas, kompetensi penggunaan media atau sumber belajar.

Dari uraian di atas dapat dipahami bahwa persepsi siswa terhadap kompetensi mengajar guru merupakan penilaian siswa terhadap keterampilan dan kemampuan guru/dosen yang dapat diamati secara langsung saat memberikan pengajaran di kelas yang meliputi kompetensi penguasaan bahan. pengelolaan program belajar mengajar, pengelolaan kelas dan penggunaan media dan sumber belajar.

\section{METODE PENELITIAN}

\section{Pendekatan Penelitian}

Penelitiaan ini berbentuk kuantitatif yang dilakukan dengan menggunakan pendekatan kualitatif. Adapun populasi target penelitian ini adalah kemampuan mengajar dosen pengajar mata kuliah kemahiran berbicara di program studi yang ada di Fakultas Sastra, Universitas Al Azhar Indonesia dari kacamata mahasiswa yang mengambil mata kuliah kemahiran berbahasa, khususnya percakapan dari empat Program Studi yang ada di Fakultas Sastra.

\section{Subjek Penelitian}

Subjek dalam penelitian ini adalah dosen pengampu mata kuliah kemahiran berbahasa di Fakultas Sastra, Universitas Al Azhar Indonesia, khususnya untuk mata kuliah kemahiran berbicara. Serta mahasiswa yanga berasal dari empat program studi yang ada di Fakultas Sastra, Universitas Al Azhar Indonesia dan mahasiswa, yang mengambil mata kuliah kemahiran berbahasa, mata kuliah percakapan, yang berjumlah lebih kurang 120 orang yang terdaftar aktif untuk tahun akademik 2014-2015, dari empat angkatan, angkatan 2011, angkatan 2012, angkatan 2013 dan angkatan 2014 .

\section{Tahapan penelitian}

Dalam penelitian terdapat dua tahap penelitian, yaitu:

1. Tahap Persiapan Penelitian

Pertama peneliti membuat pedoman pengumpulan data yang disusun berdasarkan demensi kebermaknaan sesuai dengan permasalahan dan pekerjaan yang ditekuni subjek. Pedoman pengumpulan data ini berisi pertanyaan-pertanyaan mendasar yang nantinya akan berkembang dalam wawancara. Setelah mendapat masukan dan koreksi dari ahli, peneliti membuat perbaikan terhadap pedoman pengumpulan data dan mempersiapkan diri untuk melakukan tindakan. Peneliti selanjutnya mencari subjek yang sesuai dengan karakteristik subjek penelitian dan selanjutnya melakukan proses pengumpulan bahan penelitian.

2. Tahap pelaksanaan penelitiaan

Peneliti membuat kesepakatan dengan subjek mengenai waktu dan tempat untuk melakukan pengisian data dan proses wawancara berdasarkan pedoman yang telah dibuat. Setelah pengisian data dan wawancara dilakukan, peneliti memindahkan hasil rekapan data dan wawancara yang dilakukan berdasarkan dalam bentuk verbatim tertulis. Selanjutnya peneliti melakukan analisis data dan interprestasi data sesuai dengan langkahlangkah yang dijabarkan pada bagian metode analisis. Setelah mendapatkan hasil dari penelitian yang dilakukan, peneliti merangkum hasilnya dalam bentuk kesimpulan, dibagian akhir peneliti memberikan saran untuk pengambangan penelitian ini selanjutnya.

\section{Teknik Pengumpulan Data}

Dalam penelitiaan ini, peneliti menggunakan dua teknik pengumpulan data, yaitu melakukan wawancara dengan responden penelitian, yang dalam hal ini mahasiswa dan melakukan observasi dilapangan yang yang dikuatkan dengan angket untuk mendapatkan data utuh terkait persepsi mahasiswa FS UAI terkait pengajaran kemahiran berbicara di FS UAI.

\section{Alat Bantu pengumpulan Data}

Dalam mengumpulkan data, untuk memperkuat penelitian ini, penulis menggunakan: pedoman wawancara, pedoman observasi dan angket penelitian.

\section{PEMBAHASAN HASIL PENELITIAN}

Berikut analisa peneliti dari hasil yang didapatkan dari rangkaian penelitian yang dilaksanakan:

\section{Profil Responden}

Adapun profil jenis kelamin responden yang tersebar dari angkatan 2011, 2012, 2013 dan 
2014 dengan jumlah total responden 120 orang sebagai berikut:

Tabel 1. Profil responden penelitian berdasarkan jenis kelamin dan asal program studi

\begin{tabular}{|c|c|c|c|c|}
\hline No & \multicolumn{2}{|c|}{ Pernyataan } & Jumlah & Prosentase \\
\hline \multirow[t]{2}{*}{1} & $\begin{array}{l}\text { Jenis } \\
\text { Kelamin }\end{array}$ & $\begin{array}{l}\text { Laki- } \\
\text { laki }\end{array}$ & 23 orang & 19.2 \\
\hline & & $\begin{array}{c}\text { Peremp } \\
\text { uan }\end{array}$ & 97 orang & 80.8 \\
\hline \multirow[t]{4}{*}{2} & $\begin{array}{l}\text { Asal } \\
\text { Prodi }\end{array}$ & $\begin{array}{c}\text { Sastra } \\
\text { Arab }\end{array}$ & 30 orang & 25.0 \\
\hline & & $\begin{array}{l}\text { Sastra } \\
\text { China }\end{array}$ & 30 orang & 25.0 \\
\hline & & $\begin{array}{c}\text { Sastra } \\
\text { Inggris }\end{array}$ & 30 orang & 25.0 \\
\hline & & $\begin{array}{l}\text { Sastra } \\
\text { Jepang }\end{array}$ & 30 orang & 25.0 \\
\hline
\end{tabular}

Mahasiswa yang dijadikan responden dalam penelitian ini berjumlah sebanyak 120 orang yang tersebar disemester yang berbeda mulai dari semester satu, tiga, lima, dan tujuh tahun akademik 2014-2015, mulai dari angkatan 2011, angkatan 2012, angkatan 2013, dan angkatan terakhir angkatan 2014 yang merupakan angkatan terbaru mahasiswa di Fakultas Sastra UAI.

\section{Persepsi mahasiswa terhadap proses pembelajaran kemahiran berbicara di empat Program Studi, Fakultas Sastra, UAI}

Tabel 2. Persepsi mahasiswa terhadap pernyataan yang menyatakan bahwa mata kuliah kemahiran berbicara perlu ada di Fakultas Sastra, UAI

\begin{tabular}{|r|r|r|r|r|}
\hline & Frequency & Percent & Valid Percent & \multicolumn{1}{c|}{$\begin{array}{c}\text { Cumulative } \\
\text { Percent }\end{array}$} \\
\hline Valid 4 & 34 & 28.3 & 28.3 & 28.3 \\
& 86 & 71.7 & 71.7 & 100.0 \\
& 120 & 100.0 & 100.0 & \\
\hline
\end{tabular}

Dari tabel diatas didapati bahwa mayoritas dan bisa dikatakan semua mahasiswa fakultas sastra yang dijadikan responden dalam penelitian ini menyadari sepenuhnya bahwa mata kuliah kemahiran berbicara perlu ada dan diajarkan di fakultas sastra UAI, mengingat penting nya kemahiran berbicara ini baik untuk kebutuhan harian mereka. Bentuk persetujuan mahasiswa tentang penting dan perlunya mata kuliah kemahiran berbicara ada di fakultas sastra UAI, terlihat dari jumlah yang menyatakan sangat setuju dengan pernyataan diatas sebanyak 86 orang atau sekitar $71.1 \%$, dan yang menyatakan setuju sebanyak 34 orang atau sekitar $28.3 \%$, total $100 \%$ tanpa ada satupun yang menyatakan tidak setuju dengan peryataan perlunya mata kuliah kemahiran berbicara ini ada di fakultas satra UAI.

Tabel 3. Persepsi mahasiswa terhadap pernyataan yang menyatakan bahwa mata kuliah kemahiran berbicara modal utama mempersiapkan diri memasuki dunia kerja

\begin{tabular}{|cc|c|c|c|c|}
\hline & & Frequency & Percent & Valid Percent & $\begin{array}{c}\text { Cumulative } \\
\text { Percent }\end{array}$ \\
\hline Valid & 2 & 1 & .8 & .8 & .8 \\
& 3 & 2 & 1.7 & 1.7 & 2.5 \\
& 4 & 39 & 32.5 & 32.5 & 35.0 \\
& 5 & 78 & 65.0 & 65.0 & 100.0 \\
& Total & 120 & 100.0 & 100.0 & \\
\hline
\end{tabular}

Dari tabel diatas didapati bahwa sebanyak 78 orang mahasiswa atau sekitar $65.0 \%$ menyatakan sangat setuju dengan pernyataan bahwa MK kemahiran berbicara modal utama mempersiapkan diri mereka memasuki dunia kerja, dan sebanyak 39 orang atau sekitar $32 \%$ meyatakan setuju. Jumlah 117 orang ini yang setuju ini merupakan jumlah mayoritas dan sesuai dengan kenyatannya mengingat pembelajaran bahasa asing di fakultas sastra UAI betul-betul diarahkan kepada kemahiran berbicara untuk mempersiapkan mahasiswa menjadi seorang yang bisa bicara dari bahasa asing yang mereka pelajari. Kita sadari atau tidak inilah tuntutan dunia kerja saat ini, dimana bisa atau tidak nya seseorang berbahasa asing tidak lagi dilihat dari kemampuan dia menguasai tata bahasa dan keilmuan teori lainnya, akan tetapi dilihat dari sejauhmana mahasiswa yang bersangkutan mampu mengunakan bahasa asing tersebut sebagai bahasa keseharian yang dipraktekan, sebagai bagian dari persiapan mereka sebelum memasuki dunia kerja.

Analisa peneliti dari poin diatas diperkuat dengan data yang didapatkan dari responden ketika ditanyakan pendapat mereka tentang kemahiran berbicara secara aktif menjadi tujuan utama pembelajaran bahasa asing di MK kemahiran berbicara FS UAI, sesuai dengan peryataan diangket No. 3 kelompok I. Dimana didapatkan data bahwa sebanyak 117 orang atau sekitar $97.5 \%$ dari responden menyatakan setuju kalau pembelajaran kemahiran berbicara bahasa asing di fakultas sastra UAI menjadi tujuan utama dalam pembelajaran bahasa. Peneliti menganggap pendapat ini memperkuat kebijakan fakultas yang mengharuskan 
kurikulum didesain untuk mengantarkan mahasiswa harus bisa bicara dari bahasa asing yang mereka pelajari. Kenyataan ini akan dipertahankan bahkan akan ditingkatkan lagi ketika pada tahun 2015-2016 ada anjuran dari pimpinan universitas dalam pengembangan kurikulum, maka arah kemahiran berbicara akan dijadikan sebagai tujuan perioritas kedepannya.

\section{Persepsi mahasiswa tentang materi atau bahan ajar mata kuliah kemahiran berbicara bahasa Asing Fakultas Sastra UAI}

Tabel 4. Persepsi mahasiswa terhadap pernyataan bahwa materi mata kuliah kemahiran

berbicara bahasa asing di FS UAI mudah dipahami

\begin{tabular}{|ll|r|r|r|r|}
\hline & & & & & \multicolumn{2}{c|}{ Cumulative } \\
& Frequency & \multicolumn{1}{|c|}{ Percent } & Valid Percent & Percent \\
\hline Valid & 2 & 1 & .8 & .8 & .8 \\
& 20 & 16.7 & 16.7 & 17.5 \\
& 80 & 66.7 & 66.7 & 84.2 \\
& 19 & 15.8 & 15.8 & 100.0 \\
& 120 & 100.0 & 100.0 & \\
\hline
\end{tabular}

Dari tabel diatas didapati data bahwa sebanyak 99 orang mahasiswa atau sekitar $82.5 \%$ menyatakan bahwa materi mata kuliah kemahiran kemahiran berbicara di fakultas sastra UAI mudah dipahami, hal ini bisa jadi disebabkan bahwa di fakultas sastra menggunakan kurikulum dan bahan ajar yang terintegrasi antara satu matakuliah kemahiran berbahasa dengan kemahiran berbahasa yang lain sehingga mahasiswa merasa ada singkronisasi materi antar matakuliah sejenis. Sumber bahan ajarpun berasal dari bahan yang sama. Sementara ada 20 orang mahasiswa atau sekitar $16.7 \%$ tidak menyatakan pendapatnya. Bisa jadi pernyataan ini mucul karena mereka belum punya dasar bahasa asing yang dipelajari sehingga merasa bahan ajar yang digunakan dianggap sulit atau tidak bisa menilai mudah atau tidaknya bahan ajar yang digunakan mereka dalam mempelajari kemahiran berbicara. Sementara ada 1 orang atau $0.8 \%$ mahasiswa menyatakan tidak setuju dengan pernyataan yang menyatakan bahwa materi mata kuliah kemahiran kemahiran berbicara di fakultas sastra UAI mudah dipahami.

Hasil yang relatif sama peneliti dapatkan dari responden ketika ditanyakan pendapat mereka tentang bahan ajar mata kuliah kemahiran berbicara di FS sudah sesuai dengan tuntutan zaman, didapati data bahwa 100 orang mahasisw atau sekitar $83.3 \%$ mahasiswa menyatakan setuju bahawa di fakultas sastra UAI sudah menggunakan bahan ajar yang sesuai dengan tuntutan zaman dan terbaru. Pendapat ini bukan rekayasa akan tetapi benar sesuai dengan kenyataannya, bias jadi hal ini disebabkan karena banyaknya kerjasama yang telah terjalin antara program studi yang ada di fakultas sastra dengan universitas atau institusi lain baik dalam dan luar negeri, yang salah satu manfaat nya adalah dalam penggunaan bahan ajar untuk mata kuliah kemahiran berbicara sudah menggunakan bahan ajar terbaru berbasis multi media. Sementara ada 19 orang mahasiswa atau sekitar $15.8 \%$ tidak menyatakan pendapatnya, dan hanya 1 orang atau $0.8 \%$ mahasiswa menyatakan tidak setuju dengan pernyataan yang menyatakan bahwa fakultas sastra UAI sudah menggunakan bahan ajar yang sesuai dengan tuntutan zaman.

Tabel 5. Persepsi mahasiswa terhadap pernyataan bahwa materi bahan ajar mata kuliah kemahiran berbicara berbasis multimedia

\begin{tabular}{|ll|r|r|r|r|}
\hline & & Frequency & Percent & Valid Percent & \multicolumn{1}{c|}{$\begin{array}{c}\text { Pumulative } \\
\text { Percent }\end{array}$} \\
\hline Valid & 3 & 31 & 25.8 & 25.8 & 25.8 \\
& 4 & 62 & 51.7 & 51.7 & 77.5 \\
& 27 & 22.5 & 22.5 & 100.0 \\
& & 120 & 100.0 & 100.0 & \\
\hline
\end{tabular}

Dari tabel diatas didapati data bahwa 89 orang atau sekitar $74.2 \%$ mahasiswa menyatakan setuju dengan pernyataan yang menyatakan bahwa bahwa materi bahan ajar mata kuliah kemahiran berbicara di FS berbasis multimedia sudah berbasis IT, sehingga MK diajarkan lebih menarik. Pembelajaran bahasa asing berbasis IT merupakan andalan dan merupakan sebuah kelaziman dan keharusan di Fakultas Sastra UAI. Disamping mengajarkan bahasa asing dengan metode klasikal, para dosen mewajibkan (memaksa) diri mereka dan mahasiswa untuk memanfaatkan IT semaksimal mungkin untuk seluruh matakuliah yang diajarkan termasuk matakuliah kemahiran berbicara. Bahkan ada beberapa jurusan di Fakultas Sastra UAI, seperti sastra arab dan sastra China menurunkan pada kurikulum 2013 satu matakuliah yang diberi nama IT arab dan IT China, matakuliah ini tidak hanya mengajarkan bahasa sebagai bahasa akan tetapi juga menjadikan bahasa sebagai alat untuk menjawab tantangan teknologi dan informasi. 
Sesuai dengan perkembangan teknologi, bahan ajar yang ada sekarang juga sudah banyak yang berbasis IT. Akan tetapi dari data yang diperoleh masih ada sebanyak 31 orang atau sekitar $25.8 \%$ mahasiswa yang tidak menyatakan pendapatnya ketika dinyatakan bahwa bahwa materi bahan ajar mata kuliah kemahiran berbicara di FS berbasis multi media. Kenyataan ini perlu dikaji lebih jauh cara pandang mereka melihat pembelajaran bahasa asing di fakultas sastra berbasis multi media atau tidak, karena memang dalam proses pembelajaran tidak selalu dosen menggunakan IT, bahkan diwaktu tertentu fokus hanya ke bahan ajar dalam bentuk buku paket atau buku ajar. Sementara tidak ada satupun mahasiswa (0\%) yang menyatakan tidak setuju pembejaran mata kuliah dan bahan ajar kemahiran berbicara di Fakultas Sastra berbasis IT dan multi media.

\section{Persepsi mahasiswa tentang metodologi yang digunakan, alat bantu dan evaluasi pengajaran mata kuliah kemahiran berbicara}

Tabel 6. Persepsi mahasiswa terhadap pernyataan bahwa dosen mengajar sesuai dengan Satuan Acuan Perkuliahan yang sudah ditetapkan diawal perkuliahan

\begin{tabular}{|ll|r|r|r|r|}
\hline & & Frequency & \multicolumn{1}{|c|}{ Percent } & Valid Percent & \multicolumn{2}{|c|}{$\begin{array}{c}\text { Cumulative } \\
\text { Percent }\end{array}$} \\
\hline Valid & 2 & 2 & 1.7 & 1.7 & 1.7 \\
& 3 & 10 & 8.3 & 8.3 & 10.0 \\
& 81 & 67.5 & 67.5 & 77.5 \\
& 27 & 22.5 & 22.5 & 100.0 \\
& 5 & 120 & 100.0 & 100.0 & \\
\hline
\end{tabular}

Salah satu syarat keberhasilan pengajaran di perguruan tinggi adalah, sejauh mana para pengajar atau dosen mengajar dengan merujuk kepada Satuan Acuan Perkuliahan (SAP) yang sudah digariskan dengan pengembanganpengembangan atau improvisasi dalam mengajar untuk pengembangan. Panduan dalam bentuk SAP perkuliahan akan mengantarkan proses pembelajaran lebih terarah dan tepat sasaran. Salah satu keluhan yang kadang muncul di pembelajaran bahasa adalah adanya oknum dosen tertentu yang sangat sibuk dengan aktifitas lain dikampus dan luar kampus sehingga terlihat kurang dalam mempersiapkan dirinya dalam mengajar, bahkan kadang sering keluar dari SAP yang sudah disepakati. Untuk mengatasi kondisi seperti ini, maka perlu diadakan sebuah monitoring yang berkesinambungan dari masing-masing Prodi dengan menugaskan ada satu dosen tetap yang memonitor dan mengevaluasi ini. Didapati data bahwa 108 orang mahasiswa atau sekitar $90.0 \%$ mahasiswa merupakan jumlah mayoritas menyatakan setuju dengan pernyataan yang menyatakan bahwa dosen fakultas sastra mengajar sesuai dengan Satuan Acuan Perkuliahan yang sudah ditetapkan diawal perkuliahan.

Pernyataan ini sejalan dengan tuntutan perkuliahan di UAI karena dosen dan program studi sebelum mengajar harus merevisi dan menetapkan SAP dari matakuliah yang diajarkan dan mensosialisasikan materi yang akan diajarkan kepada mahasiswa yang diajar. 10 orang mahasiswa atau sekitar $8.3 \%$ mahasiswa tidak menyatakan pendapatnya. Sementara hanya 2 orang mahasiswa atau sekitar $1.7 \%$ tidak setuju dengan pernyataan yang menyatakan bahwa dosen Fakultas Sastra mengajar sesuai dengan Satuan Acuan Perkuliahan yang sudah ditetapkan diawal perkuliahan.

Tabel 7. Persepsi mahasiswa terhadap pernyataan bahwa dosen pengajar mata kuliah kemahiran berbicara menguasai bahan ajar yang akan diajarkan

\begin{tabular}{|ll|r|r|r|r|}
\hline & & Frequency & \multicolumn{1}{|c|}{ Percent } & Valid Percent & \multicolumn{2}{c|}{$\begin{array}{c}\text { Cumulative } \\
\text { Percent }\end{array}$} \\
\hline Valid & 9 & 7.5 & 7.5 & 7.5 \\
\cline { 2 - 6 } & 4 & 59 & 49.2 & 49.2 & 56.7 \\
& 52 & 43.3 & 43.3 & 100.0 \\
& Total & 120 & 100.0 & 100.0 & \\
\hline
\end{tabular}

Dari tabel diatas didapati data bahwa 111 orang mahasiswa atau sekitar $92.5 \%$ mahasiswa Fakultas Sastra yang dijadikan responden menyatakan setuju dengan pernyataan yang menyatakan bahwa dosen pengajar mata kuliah kemahiran berbicara menguasai bahan ajar yang akan diajarkan. Menurut analisa peneliti. Persepsi mahasiswa terhadap dosen yang mengajar kemahiran berbahasa menguasai bahan ajar yang diajarkan kepada mahasiswa dengan baik mengacu kepada pengalaman dan latar belakang dosen yang mengajar kemahiran berbicara bahasa asing di UAI.

Mayoritas dosen telah menyelesaikan pendidikannya di jenjang S2 dan bahkan ada yang sudah menyelesaikan pendidikannya S3, baik lulusan dalam maupun luar negeri, pada saat yang sama dosen-dosen ini dibimbing dan 
diarahkan oleh dosen senior dan guru besar yang mempunyai keilmuan dan pakar dibidangnya. Sinkronisasi antara dosen muda dan dosen senior memberikan kontribusi lebih dalam penguasaan bahan ajar untuk dijakarkan kepada mahasiswa. Ketika ditanyakan apakah dosen matakuliah kemahiran berbicara mengajar dengan metode yang menyenangkan dan tidak membosankan mahasiswa, mayoritas mahasiswa menyatakan setuju, sebanyak 91 orang mahasiswa atau sekitar $76.6 \%$ mahasiswa.

Pengakuan ini tentunya didasari oleh kenyataan dilapangan yang dilihat dan dirasakan oleh mahasiswa dari empat program studi yang ada di Fakultas Sastra UAI ketika diajar baik dikelas maupun diluar kelas. Tentunya seorang pengajar tidak saja mengajar berdasarkan bahan ajar, akan tetapi perlu inovasi yang muncul dari semangat ingin memberikan hasil yang terbaik kepada anak didiknya. Sementara 20 orang mahasiswa atau sekitar $16.7 \%$ tidak menyatakan pendapatnya, dan 2 orang dari mahasiswa atau sekitar $1.7 \%$ mahasiswa tidak setuju dengan pernyataan yang menyatakan bahwa dosen mengajar dengan metode yang menyenangkan dan tidak membosankan mahasiswa.

Tabel 8. Persepsi mahasiswa terhadap pernyataan yang menyatakan bahwa dosen pengajar mata kuliah kemahiran berbicara menggunakan alat bantu dalam mengajar selain buku ajar

\begin{tabular}{|rl|r|r|r|r|}
\hline & & & & \multicolumn{2}{|c|}{ Cumulative } \\
& & Frequency & \multicolumn{1}{|c|}{ Percent } & Valid Percent & \multicolumn{2}{|c|}{ Percent } \\
\hline Valid & 2 & 6 & 5.0 & 5.0 & 5.0 \\
& 29 & 24.2 & 24.2 & 29.2 \\
& 62 & 51.7 & 51.7 & 80.8 \\
& 23 & 19.2 & 19.2 & 100.0 \\
& 5 & 120 & 100.0 & 100.0 & \\
\hline
\end{tabular}

Dari tabel diatas didapati data bahwa 85 orang mahasiswa atau sekitar $70.9 \%$ mahasiswa menyatakan setuju dengan pernyataan yang menyatakan bahwa dosen pengajar mata kuliah kemahiran berbicara di FS menggunakan alat bantu dalam mengajar selain buku ajar atau referensi. Pernyataan ini sesuai dengan kenyataan yang ada di proses pembelajaran kemahiran berbicara di FS UAI. Setiap kelas telah disediakan seperangkat alat penunjang proses pembelajaran berupa LCD, proyektor dan komputer yang online dengan fasilitas internet. Untuk bahan yang dijadikan sebagai tema pembicaraan dosen dan mahasiswa bisa langsung online dengan fasilitas yang ada di masing-masing lab bahasa, apakah menggunakan TV parabola ataupun menggunakan internet yang ada di setiap meja mahasiswa. Pembelajaran bahasa asing berbasis multimedia di FS UAI menjadi sebuah keunggulan tersendiri dalam pembelajaran bahasa asing di perguruan tinggi Indonesia. 29 orang mahasiswa atau $24.2 \%$ tidak menyatakan pendapatnya, hal ini bisa jadi disebabkan karena kreatifitas mahasiswa berbeda antara satu dengan yang lainnya. Ada sekelompok mahasiswa yang berinisiatif mengembangkan materi yang diterima di kelas dengan aktifitas seaching di internet, dan ada juga mahasiswa yang hanya mengandalkan pengajaran bahasa asing berbasis kelas tanpa keinginan untuk ambil bagian dalam memanfaatkan media yang ada. Sementara 6 orang mahasiswa atau sekitar $5 \%$ tidak setuju dengan pernyataan yang menyatakan bahwa dosen pengajar mata kuliah kemahiran berbicara di FS menggunakan alat bantu dalam mengajar selain buku ajar.

Tabel 9: Persepsi mahasiswa terhadap pernyataan bahwa dosen mata kuliah kemahiran berbicara memberikan penilaian sesuai dengan peraturan yang berlaku di UAI

\begin{tabular}{|l|r|r|r|r|}
\hline & & & & Cumulative \\
& Frequency & Percent & Valid Percent & Percent \\
\hline Valid & 1 & .8 & .8 & .8 \\
& 8 & 6.7 & 6.7 & 7.5 \\
& 76 & 63.3 & 63.3 & 70.8 \\
& 35 & 29.2 & 29.2 & 100.0 \\
5 & 120 & 100.0 & 100.0 & \\
\hline
\end{tabular}

Penilaian dalam proses pembelajaran bahasa asing merupakan alat ukur penentu ketercapaian proses pembelajaran yang dilaksanakan. Pembelajaran yang baik harus menggunakan alat ukur atau evaluasi yang baik pula. Sering dosen terjebak dalam memberikan jenis alat ukur untuk melihat sejauh mana keberhasilan pembelajaran yang dilaksanakan di kelas. Penilaian yang ideal disamping mengacu kepada penilaian tengah semester, akhir semester dan tugas, juga harus memperhatikan ketercapaian materi ajar perkali pertemuan, harian, mingguan ataupun bulanan.

Jika seorang dosen hanya mengambil nilai mahasiswa dari ujian tengah dan akhir semester saja maka alat ukur menjadi tidak tepat karena bisa jadi pada saat ujian dilaksanakan kondisi mahasiswa tidak berada dalam keadaan prima. Analisa peneliti diatas dibuktikan dengan hasil yang didapatkan ketika disampaikan kepada 
responden dalam penelitian ini ketika ditanyakan persepsi mereka tentang dosen mata kuliah kemahiran berbicara di FS Memberikan penilaian sesuai dengan peraturan yang berlaku di UAI. Didapati data bahwa 109 orang mahasiswa atau sekitar $92.5 \%$ menyatakan setuju bahwa dosen FS UAI telah melakukan proses penilaian sesuai dengan peraturan yang berlaku dan ideal dalam proses pengajaran. Sementara 8 orang mahasiswa atau $6.7 \%$ tidak menyatakan pendapatnya, dan sebanyak 1 orang mahasiswa atau $0.8 \%$ menyatakan tidak setuju dengan pernyataan yang menyatakan bahwa dosen mata kuliah kemahiran berbicara di FS telah memberikan penilaian ketika mengajar kemahiran berbicara sesuai dengan peraturan yang berlaku di UAI.

\section{Persepsi mahasiswa tentang dosen pengajar mata kuliah kemahiran berbicara di empat program studi Fakultas Sastra}

Tabel 10: Persepsi mahasiswa terhadap pernyataan bahwa dosen yang mengajar mata kuliah kemahiran berbicara memiliki kemampuan bahasa asing dengan baik

\begin{tabular}{|ll|r|r|r|r|}
\hline & & & & & Cumulative \\
& & Frequency & Percent & Valid Percent & Percent \\
\hline Valid & 3 & 7 & 5.8 & 5.8 & 5.8 \\
& 4 & 52 & 43.3 & 43.3 & 49.2 \\
& 51 & 50.8 & 50.8 & 100.0 \\
& Total & 120 & 100.0 & 100.0 & \\
\hline
\end{tabular}

Dari tabel diatas didapati data bahwa 113 orang mahasiswa atau sekitar $94.1 \%$ mahasiswa menyatakan setuju dengan pernyataan yang menyatakan bahwa dosen yang mengajar mata kuliah kemahiran berbicara di FS UAI memiliki kemampuan bahasa asing dengan baik. Persepsi mahasiswa terhadap kemampuan para dosen yang mengajar kemahiran berbicara ini merupakan bukti nyata bahwa tingkat keilmuan para dosen bahasa asing di FS UAI cukup bisa diandalkan, hal ini boleh jadi disebabkan karena rata-rata para dosen yang mengajar sudah minimal S2 dan cukup banyak yang telah menyelesaikan pendidikannya di jenjang S3 di dalam dan luar negeri dan juga keberadaan beberapa orang guru besar yang sangat pakar di bidangnya. Latar belakang pendidikan dosen ini memberikan kontribusi lebih dalam proses pembelajaran bahasa asing yang dilaksanakan. Sementara hanya 7 orang mahasiswa atau sekitar 5.8\% mahasiswa yang tidak menyatakan pendapatnya.
Tabel 11: Persepsi mahasiswa terhadap pernyataan yang menyatakan bahwa dosen yang mengajar mata kuliah kemahiran berbicara memiliki kemampuan mengajar yang baik

\begin{tabular}{|ll|r|r|r|r|}
\hline & & & & \multicolumn{2}{c|}{ Cumulative } \\
& & Frequency & Percent & Valid Percent & \multicolumn{2}{c|}{ Percent } \\
\hline Valid & 1 & .8 & .8 & .8 \\
& 3 & 2.5 & 2.5 & 3.3 \\
& 78 & 65.0 & 65.0 & 68.3 \\
& 38 & 31.7 & 31.7 & 100.0 \\
& 120 & 100.0 & 100.0 & \\
\hline
\end{tabular}

Dari tabel diatas didapati data bahwa 116 orang mahasiswa atau sekitar $96.7 \%$ mahasiswa menyatakan setuju dengan pernyataan yang menyatakan bahwa dosen yang mengajar mata kuliah kemahiran berbicara di FS UAI memiliki kemampuan mengajar yang baik. Pernyataan ini sejalan dengan pernyataan sebelumnya dimana mahasiswa mayoritas menyatakan bahwa disamping para dosen yang mengajar di FS UAI menguasai bahan ajar dengan baik, pada saat yang sama mereka juga memiliki kemampuan mengajar sesuai dengan apa yang diharapkan oleh mahasiswa. Ada keseimbangan antara penguasaan bahan ajar dan kemampuan mengajar, hal ini bisa jadi merupakan dampak dari keseimbangan antara pengalaman mengajar dosen senior dengan dosen muda yang saling melengkapi antara satu dengan lainnya. Ada 3 orang mahasiswa atau sekitar $2.5 \%$ tidak menyatakan pendapatnya. Sementara hanya 1 orang mahasiswa atau sekitar $0.8 \%$ mahasiswa tidak setuju dengan pernyataan yang menyatakan bahwa bahwa dosen yang mengajar mata kuliah kemahiran berbicara di FS UAI memiliki kemampuan mengajar yang baik.

Saran dan masukan mahasiswa, Fakultas Sastra UAI kepada program studi dan dosen pengajar kemahiran berbicara terkait penelitian yang dilaksanakan

Ketika ditanyakan pendapat dan saran mahasiswa Fakultas Sastra terkait perkuliahan kemahiran berbicara yang sudah berjalan di Fakultas Sastra dan rencana pengambangan kedepan, mahasiswa memberikan usulan, kritikan yang sifatnya membangun. Peneliti mencoba menarasikan kembali dengan bahasa yang baik, diantara usulan mahasiswa adalah:

- Mahasiswa Fakultas Sastra UAI berharap tujuan pengajaran bahasa asing di FS UAI lebih difokuskan untuk kemahiran berbicara dan penguasaan kemahiran lainnya yang 
diturunkan dalam kurikulum masing-masing Program Studi dan dikawal pelaksanaanya oleh para dosen, sehingga bisa mengantarkan mahaiswa kepada tingkat kemahiran yang ingin dicapai sesuai dengan standar pengajaran masing-masing bahasa yang ada di FS UAI.

- Mahasiswa Fakultas Sastra UAI berharap agar para dosen yang mengajar kemahiran berbicara di Fakultas Sastra UAI, selain native spaker, harus berusaha untuk meningkatkan kemampuan mereka dalam bidang kompetensi keilmuan bahasa, metodologi mengajar, interaksi dengan mahasiswa dan lingkungan guna untuk meningkatkan susana pembelajaran yang interaktif dari mata kuliah yang diajarkan.

- Mahasiswa Fakultas Sastra UAI berharap agar pengajaran mata kuliah kemahiran berbicara di FS UAI harus memiliki standarisasi dan alat ukur yang ingin dicapai dalam pembelajaran, sebaimana yang sudah ada di beberapa bahasa asing yang ada seperti TOEFL untuk bahasa Inggris, TOAFL untuk bahasa Arab, HSK untuk bahasa China dan N1-N5 untuk bahasa Jepang. Keberadaan standarisasi kebahasaan ini dijadikan barometer dan target capaian dalam mengajar kemahiran tertentu, disamping penunjang kemahiran yang empat lainnya.

- Mahasiswa Fakultas Sastra UAI berharap agar dosen hadir mengajar tepat waktu sesuai dengan jadwal yang sudah ditentukan. Adanya kuliah pengganti merupakan solusi dari batalnya satu tatap muka dilakukan, akan tetapi terlalu banyak kuliah pengganti juga berdampak psikis kepada mahasiswa karena nait awal mereka keluar dari rumah datang ke kampus untuk belajar, akan tetapi sesampai di kampus dosen yang diharapkan datang memberikan ilmu nya, tidak bisa hadir karena alasan tertentu, bahkan ada dosen yang tidak bisa masuk mengajar dengan alasan sibuk, yang seharusnya tidak mengorbankan jadwal kuliah yang sudah disepakati diawal.

\section{PENUTUP}

\section{Kesimpulan}

Berdasarkan data, uraian dan analisis deskriptif yang didapatkan oleh peneliti pada bab IV, berikut dirumuskan simpulan yang didapatkan oleh peneliti:

1. Mahasiswa FS memandang bahwa materi atau bahan ajar yang digunakan dan diajarkan oleh para dosen pengampu mata kuliah kemahiran berbicara bahasa asing di FS UAI sudah sesuai dengan standarnya dan bisa mengantarkan mahasiwa kepada keahlian berbahasa yang mereka inginkan.

2. Menurut mahasiswa FS, sistematika pengajaran mata kuliah kemahiran berbicara sudah cukup sistematis sesuai SAP yang disiapkan diawal, serta mengacu kepada penggunaan bahan ajar yang digunakan. Penguasaan materi dan metode mengajar oleh dosen pun dipersepsikan secara positif oleh mereka.

3. Menurut mahasiswa FS, secara umum kemampuan dosen dalam mengajar kemahiran berbicara cukup baik dan siap. Penampilan dan komunikasi personal dosen dengan mahasiswa cukup positif sehingga ikut mendorong dan memotivasi mahasiswa untuk mempelajari kemahiran bahasa asing dengan baik. Situasi itu dibarengi pula dengan komitmen dosen untuk menegakkan disiplin menegakan aturan yang berlaku di UAI.

4. Mahasiswa FS UAI melihat bahwa dosen pengajar kemahiran berbicara sudah menerapkan proses penilaian secara adil dan tidak dipengaruhi kedekatan dengan mahasiswa dan telah sesuai dengan standar kemampuan mahasiswa yang bersangkutan, hanya perlu peningkatan alat ukur, agar proses pembelajaran lebih tepat sasaran kedepannya.

\section{Saran dan Rekomendasi}

1. Univesitas diharapkan kedepannya perlu memberikan dukungan lebih terkait pembelajaran mata kuliah kemahiran berbicara di FS UAI dengan memberikan fasilitas pendukung proses pembelajaran berbahasa asing dengan standar pembelajaran yang ideal.

2. Program studi diharapkan bisa memfasilitasi keberadaan ruang yang bisa dijadikan sebagai tempat untuk bahasa asing ini diterapkan oleh mahasiswa dalam mempraktekan kemahiran berbahasa asing yang mereka miliki, selain kelas di MK yang diajarkan, karena penciptaan suatu lingkungan bernuansa budaya dari bahasa yang dipelajari. 
3. Para dosen diharapkan untuk senantiasa berusaha untuk meningkatkan kompetensi keilmuan mereka, kompetensi mengajar dan kompetensi pendukung lainnya, dengan cara mengikuti pelatihan-pelatihan serta peningkatan kompetemnsi seperti, studi banding, pelatihan, seminar dll, sehingga kesemua itu bisa berimbas untuk peningkatan mutu lulusan mahasiswa FS UAI.

\section{DAFTAR PUSTAKA}

[1] Abu Ahmadi, Strategi Belajar Mengajar (Cet. I; Bandung: CV. Pustaka Setia, 1997)

[2] Azhar Arsyad, Dasar-Dasar Penguasaan Bahasa Arab (Cet.I; Yogyakarta: Pustaka Pelajar, 2001)

[3] Prof. Dr. Aziz Fahrurrazi, MA, Erta Mahyudin, M. Pd, Pembelajaran Bahasa Arab, Direktorat Jendral Pendidikan Islam, DEPAG RI, 2009

[4] Ruslan. A. Tabrani, Astang Kusnidar dan Zainal Arifin, Pendekatan dalam Proses Mengajar, Bandung: Remaja Karya, 1989

[5] Ahmad Fuad Effendy, Metodologi Pengajaran Bahasa Arab, 2005, Penerbit Misykat Malang.

[6] Makmun Abin Syamsududin, Psikologi Pendidikan, Bandung, Remaja Rosdakarya, 1990
[7] Faisal Hendra, Penggunaan Alat Bantu dalam Pengajaran Bahasa Arab di Indonesia, Antara harapan dan Tantangan, Desertasi S3, 2006

[8] Borang Sastra Arab, Sastra China, Sastra Inggris, Sastra Jepang, Pengajuan Akreditasi Jurusan yang ada di Fakultas Sastra UAI tahun 2010 dan 2013.

[9] Portfolio Fakultas dan Borong Institusi Fakultas Sastra 2014, Akreditasi Sastra Arab 2014

[10] http://www.psbpsma.org/content/blog/pengertianpendekatan-strategi-metode-teknik-taktikdan-model-pembelajaran, [diakses pada bulan Juni 2015]

[11] http://akhmadsudrajat.wordpress.com/daft ar-isi-makalah-pendidikan/

[12] http://id.shvoong.com/socialsciences/communication-media-studies/,

[13] http://www.masbow.com/2009/08/apa-itupersepsi.html, [diunduh pada bulan Juni 2015]

[14] http://panduanguru.com/pengertianbelajar-dan-mengajarl, [diunduh pada bulan Juni 2015]

[15] http://repository.usu.ac.id/bitstream/12345 6789/34483/3/Chapter\%20II.pdf

[16] http://eprints.ung.ac.id/5762/3/2012-186205-121409048-bab206092012013521.pdf, [diunduh pada bulan Juni 2015]

[17] http://www.slideshare.net/septianraha/ko mpetensi-mengajar, [diunduh pada bulan Juni 2015] 